Důležitou hodnotou, již si ze setkávání a rozhovorů s Jiřinou odnáším, je propojování, hledání mostů a porozumění mezi zdánlivě odlišnými světy, které ale mohou být v určitém kontextu i spojenci.

\title{
Osobní vzpomínka na Jiřinu Šiklovou
}

\section{Lucie Vidovićová}

Je smutnou souhrou osudu, že toto číslo časopisu Gender a výzkum s podtitulem "Gender, věk a stárnutí" vychází v době, kdy odešla první dáma tématu Jiřina Šiklová (*17. 6. 1935 - † 22. 5. 2021). Její Deník staré paní jsem četla už jako doktorská studentka ve vydání nakladatelství Kalich z roku 2003. Dříve jasně růžové desky knižky jsou dnes vybledlé do jemně rưžového odstínu, který kontrastuje s křiklavě růžovou fixou označující mé poznámky v textu: „Lidé se raději přiznávají k tomu, že jsou nemocní, než k tomu, že jsou staří" (s. 53), "(d)neska nebereme život jako úděl a chceme být soběstační i ve chvílích, kdy sotva dechu popadáme" (s. 58). ${ }^{1}$

Když jsem se probírala historií e-mailů, narazila jsem na naši první korespondenční výměnu z dubna roku 2005. Prosila jsem ji o nějaké názory do projektu, který se věnoval konceptu aktivního stárnutí: "Mám vám odpovídat do e-mailu? Tak to vlepím do toho celku, to bude jako internetová diskuse? Zdravím Jiřina Šiklová," zněla její první odpověd". „Tak to pišu prímo do toho, opravdu jako asociace. Promiňte, že .... nějak je toho ted'moc, " napsala záhy omluvně, aby tím jen podtrhla, že žádný dotaz, byt' by přišel do toho nejhektičtějšího období, nezůstane nezodpovězen.

Tehdy její hlavní témata, jak podpořit koncept aktivního stárnutí, byla dvě - občanská společnost a vzdělávání: „Občanská společnost - bariérou je nedostatek podpory rozvoje občanské společnosti z hlediska státu, podnikatelů, EU..., nebot’ zde není dostatečný počet velkorysých, bohatých donátorư pro tuto oblast. Občanská společnost je $v$ ČR přehližena. Projekty a psani projektů a žádáni o granty je př́liš zprofesionalizováno, nově začínajíci "nedosáhnou” na poskytované penize. EU a její granty nutí k tzv. sitování a tato schopnost překračuje možnosti a schopnosti stárnoucích lidí tyto kontakty navazovat a takto formálně náročné projekty formulovat. Proto řada lokálních iniciativ starých lidí není realizována - nevytváří se subkultura starých lidí, nebot formálně je to pro ně náročné. Obdobně toto platí i pro svépomocné skupiny starých. Dưchodový systém - bariérou je interpretace důchodu jako "daru, výsledku

\footnotetext{
1 Šiklová, J. 2003. Deník staré paní. Praha: Kalich.
} 


\section{NV ZPRÁVY / INFORMATION}

péče státu, společnosti o staré lidi, tedy oblast předsudkü, hodnocení a sebehodnocení starých a jejich sebepodceňování, prípadně chápání sebe jako „prítěžujicich". Reprodukce tohoto pohledu na staré u mladších věkových skupin. Naučená bezmocnost na podkladě desitek let existujicího státního systému, tzv. socialistického, a tím pádem přenášení odpovědnosti ze sebe na druhé, a hlavně na společnost, která se "má" postarat. Bariérou na pracovním trhu je zdưrazňováni "mladého" kolektivu, týmu apod. a z toho vyplývajicí sebepodceňováni starých lidí a averze vưči nim. Rychle se měníci technologie postupů v práci a NEEXISTENCE základů specifické výuky starých lidí, tedy neexistence „pedagogických postupü, metodologie zvyšování kvalifikace pro stárnoucí věkové skupiny" (osobní korespondence z 1. 5. 2005). Pojem "gerontoandragogika" je přitom další, který na mne křiklavě růžově září na straně 104 Deníku staré paní a jehož absence ve veřejném diskursu a politických prioritách stále zoufale přetrvává. Bohužel ani "mladý a dynamický” kolektiv v náborových inzerátech není žádnou minulostí.

Do symbolického sousedství nás později kolem roku 2011-2012 svedl Jiří Hrabě, šéfredaktor časopisu Vital Plus, vydávaného pražskou organizací Elpida. Jiří nás vyzval k mezigeneračnímu sociologickému duelu na stránkách rubriky Pohledy. Tam vedle sebe na jedné straně ve dvou sloupcích sršela naše výměna názorů na témata jako prarodičovství nebo význam prostoru a prostředí ve stáří. Nevím, nakolik jsme splnily představu editora, že pưjdeme generačně „na nože”, protože já jsem ve svém mladickém nerozumu „házela" sociologickými koncepty, zatímco ona totéž vyjádřila srozumitelně ve své vlastní zkušenosti.

Postupem času jsem se snažila vybudovat tradici každoročního krátkého e-mailu jako prání k svátku. Byla jedinou Jiřinou, kterou jsem až donedávna znala, a to pro mne byla záminka se vždy alespoň krátce „připomenout” a poptat se, jak se má. „Díky, mám se dobře, ale honím se snad ještě více než v době, kdy jsem nebyla ještě v penzi. Asi proto, že vím, že čas se člověku krátí a prátelé odcházejí. Podnikáte něco k tomu roku aktivního stáríi? Nějaké výzkumy? Jste ted'zde, nebo s manželem někde ve Slovinsku? (nepletu si to?) Na čem pracujete? Já vedle těch rozhovorů ted'něco dodělávám k více jak 40 let starému rukopisu (svému rukopisu, který nemohl být již vydán) o nové levici a hledám paralely. Jsou velké, .... až na to, že tehdy si mohli promitat své ideály do Číny, třetího světa, ... atd. Dnes? Snad do Grónska či Antarktidy, až jednou roztaje. Tak diky za gratulaci - Jiřina Šiklová" (osobní korespondence z 15. 2. 2012).

Když se světem, a nakonec i Českou republikou, začala šiřit pandemie covid-19, věděli jsme, že je zle. Ani ne tak ze zdravotního nebo ekonomického hlediska, tato rizika hlubokých dopadů na společnost neznámého trvání jsme si na jaře 2020 ještě nikdo neuměli představit, ale už tehdy začínalo být jasné, že se "cosi" stane se "seniory", tedy nejen s jejich těly, s jejich zdravotním stavem a úmrtností, ale vưbec s tím, kdo a kým jsou ve společnosti, jak je budována jejich skupinová i osobní identita a do 
jakých struktur budou rámováni. Moje poslední zahraniční cesta tehdy na jaře byla na závěrečnou konferenci evropské akce COST nazvané „ROSEnet - Reducing Old-Age Social Exclusion: Collaborations in Research and Policy", které predsedal Kieran Walsh z irského města Galway. Většina z téměř dvou set účastníků tehdy do Bruselu sice ještě přiletěla, ale ze dne na den jsme museli najít nové místo pro konání konference, protože budovy Evropské komise se už z epidemiologických důvodů uzavíraly pro veřejnost. Vnímali jsme, že se děje něco historického i pro náš obor a naše téma. Stárnutí si těžko mohlo předplatit lepší reklamu, ale zároveň nás výsledky projektu varovaly, že multidimenzionální sociální exkluze ted' nabijí novou munici. Profesor Walsh proto záhy definoval čtyři klíčové body o důstojnosti starších dospělých, které bychom měli mít při boji s pandemií na paměti tak, abychom "s vaničkou nevylili i dítě". Ze čtyř bodů se stala tzv. galwayská výzva "Zastavme ageismus v době koronaviru", kterou postupně podepsalo přes 500 signatářu z řad osobností, profesionálů i "běžných" seniorů a seniorek. Jiřina Šiklová ji podepsala jako první z oslovených. Symbolicky pro náš vztah to byl zase duben, tentokrát 14. 4. 2020: „ano, chci se připojit, prĭpište tam moje jméno - tj. Jiřina Šiklová."

Naposledy jsem Jiřinu viděla o deset dní později, bez týdne přesně po patnácti letech od jejího prvního e-mailu. To setkání si pamatuji zcela živě. Bylo to při príležitosti pohřbu socioložky Markéty Sedláčkové, na němž promlouvala ke shromážděným smutečním hostům. Vzhledem $\mathrm{k}$ truchlivé př́ležitosti mi připadalo vhodné se v konverzaci zaměřit na něco optimistického, a tak jsem se Jiřiny zeptala, co nového píše. "Nic. Až Vám bude tolik co mě, už vám to taky nebude pripadat tak dưležité se za něčím honit," odpověděla pevným hlasem, aby mi zavdala na dlouhé dny přemýšlení o konečnosti, pravých významech života a nesmysInosti běhu připomínajícího křečka v kulatém bubínku. Měla odpracováno. Vše podstatné už bylo řečeno a je nyní na nás jako pokračující generaci nést tyto odkazy dál, a dá-li Bủh, také je přetavit v lepší společnost. Necht' duše Jiřiny Šiklové odpočívá v pokoji, ale její ideje burcují dál!

\footnotetext{
2 Podrobněji: http://rosenetcost.com/combatting-exclusions-and-ageism-for-older-people-during-thecovid-19-pandemic/. Čtyři teze tzv. galwayské výzvy: 1) Reakce státu a společnosti na covid-19 si musí být vědoma prímých vyloučení postihujících starší občany jako výslednice politik a strategií, jež byly zavedeny v rámci boje proti viru, a tam, kde je to možné, kompenzovat tyto negativní okolnosti podporou a aktivitou. 2) Neustále musíme dbát na to, aby ošetření pacientů nakažených covidem-19 i další formy alokace zdrojů v souvislosti s krizí byly prováděny na základě potřebnosti, a nikoliv na základě prosté věkové hranice. 3) Při zavádění politik a strategií k ochraně starších lidí během pandemie covidu-19 nesmíme ignorovat heterogenitu starší populace ani chápat starší občany jako vysoce zranitelné a pasivní jedince a ignorovat tak jejich př́spěvek k úsilí postavit se pandemii. 4) Politiky a strategie zaměřené na boj proti covidu-19 nesmí být postavené na problematizaci stárnutí a starších lidí v kontextu krize, ani sloužit k destabilizaci výrazné solidarity mezi generacemi, jíž jsme v současné době svědky. Celá kampaň je přístupná česky na: https://www.ageismus.cz/.
} 